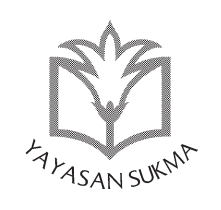

SUKMA: JURNAL PENDIDIKAN

ISSN: 2548-5105 (p), 2597-9590 (e)

Volume 3 Issue 2, Jul-Dec 2019, pp. 137-168

https://doi.org/10.32533/03201.2019

www.jurnalsukma.org

\title{
KEBIJAKAN KURIKULUM DAN DINAMIKA PENGUATAN PENDIDIKAN KARAKTER DI INDONESIA
}

\section{Mohammad Ariandy}

Universitas Islam Negeri (UIN) Sunan Kalijaga Yogyakarta, Indonesia

moh.ariandy@hotmail.com

\section{Abstract}

Artikel ini intens menyoroti hal-hal yang melatarbelakangi kebijakan kurikulum pendidikan, khususnya pendidikan karakter dalam bingkai Program 'penguatan pendidikan karakter' (PPK). Hal tersebut tentunya tidak lepas dari inovasi kebijakan kurikulum yang dikawinkan dengan gagasan-gagasan pemerintah, yang dibalut dalam sebuah gerakan dengan label "revolusi mental" yang terintegrasi dalam sebuah kurikulum nasional yang sedang berjalan. Persoalan yang akhirnya menjadi pokok perhatian dalam artikel ini, 
yakni bagaimana aktor-aktor tertentu memanfaatkan konstruksi pengetahuan tentang dinamika perubahan kurikulum dan urgensitas pendidikan karakter dalam pendidikan nasional. Proses di mana pengetahuan tentang kurikulum nasional dan skema penyelesaian huru-hara implementasi kebijakan kurikulum dikonstruksi, menggambarkan bagaimana aktor-aktor menjalankan kekuasaan. Teori governmentality Michel Foucault secara efektif menunjukkan wacana yang hanya menjadi medium mengantarkan kekuasaan. Kekuasaan justru akan semakin efektif jika berhasil menggerakkan serta mengarahkan individu-individu untuk bertingkah laku secara sukarela. Keadaan sebisa mungkin dibuat normal-normal saja, dengan begitu, akan tercipta masyarakat yang berdisiplin, taat regulasi, dan membatasi diri pada aturan-aturan yang telah diciptakan. Kekuasaan bukan lagi sekadar mengontrol, ia bahkan didukung oleh individu-individu yang merasa menjadi bagian darinya, sehingga masing-masing dari mereka mengambil sikap "etis" terhadap persoalan-persoalan atau wacana-wacana yang dihadapi.

Keywords: Diskursus Kurikulum, Governmentality, Pendidikan Karakter

\section{A. Pendahuluan}

Sebagai suatu proses yang banyak menentukan corak dan kualitas kehidupan individu dan masyarakat, tidak mengherankan apabila semua pihak memandang pendidikan sebagai wilayah strategis bagi kehidupan manusia sehingga program-program dan proses yang ada di dalamnya dapat dirancang, diatur, dan diarahkan sedemikian rupa untuk mendapatkan output yang diinginkan. Ini yang menjadi salah satu alasan mengapa suatu Negara sangat perlu dan menyediakan anggaran dalam jumlah 
yang besar untuk bidang pendidikan. Semua itu dilakukan dalam rangka membangun suatu sistem pendidikan yang memiliki karakteristik, kualitas, arah, dan output yang diinginkan. Untuk memastikan terwujudnya keinginan tersebut, banyak Negara yang menerapkan kontrol yang sangat ketat terhadap program-program pendidikan, baik yang diselenggarakan sendiri oleh negara maupun yang diselenggarakan oleh masyarakat (Maimunah 2013, 131). Pemerintah adalah bagian dari Negara yang paling kasat mata dan dapat juga menjadi bagian paling penting dan paling aktif dari Negara, tetapi pemerintah bukanlah keseluruhan dari Negara. Negara terdiri dari berbagai institusi yang masing masing memiliki fungsi dan peran tersendiri dalam tatanan kehidupan kenegaraan.

Naskah Kebijakan Nasional Pembagunan Karakter Bangsa, diuraikan bahwa, ada beberapa alasan mendasar yang melatari pentingnya pembangunan karakter bangsa, baik secara filosofis, ideologis, normatif, historis maupun sosiokultural. Secara filosofis, pembangunan karakter bangsa merupakan sebuah kebutuhan asasi dalam proses berbangsa karena hanya bangsa yang memiliki karakter dan jati diri yang kuat yang akan survive sebagai suatu bangsa. Secara ideologis, pembangunan karakter merupakan upaya mengejawantahkan ideologi Pancasila dalam kehidupan berbangsa dan bernegara. Secara normatif, pembangunan karakter bangsa merupakan wujud nyata langkah mencapai tujuan bangsa yaitu melindungi segenap bangsa Indonesia dan seluruh tumpah darah Indonesia, memajukan kesejahteraan umum, mencerdaskan kehidupan bangsa, ikut melaksanakan ketertiban dunia berdasarkan kemerdekaan, perdamaian abadi, dan keadilan sosial. Secara historis, pembangunan karakter bangsa merupakan sebuah dinamika inti proses kebangsaan yang terjadi tanpa henti dalam kurung sejarah, baik pada zaman penjajahan maupun di zaman kemerdekaan. Secara kultural, pembangunan karakter bangsa merupakan suatu keharusan dari suatu bangsa yang multikultural (Kemendiknas 2010,1).

Penguatan karakter menjadi salah satu program prioritas Presiden Joko Widodo (Jokowi) dan Wakil Presiden Jusuf Kalla di 


\section{Mohammad Ariandy}

masanya. Dalam nawa cita disebutkan bahwa pemerintah akan melakukan revolusi karakter bangsa. Kementerian Pendidikan dan Kebudayaan mengimplementasikan penguatan karakter penerus bangsa melalui gerakan Penguatan Pendidikan Karakter (PPK) yang digulirkan sejak tahun 2016. Sesuai arahan Presiden Joko Widodo, pendidikan karakter pada jenjang pendidikan dasar mendapatkan porsi yang lebih besar dibandingkan pendidikan yang mengajarkan pengetahuan. Untuk sekolah dasar sebesar 70 persen, sedangkan untuk sekolah menengah pertama sebesar 60 persen. "Gerakan Penguatan Pendidikan Karakter sebagai fondasi dan ruh utama pendidikan," pesan Menteri Pendidikan dan Kebudayaan (Mendikbud) Muhadjir Effendy (Kemendikbud 2019). Mengingat lembaga pendidikan sangat efektif dalam pembentukan karakter, maka yang diperlukan model pengelolaan pendidikan yang memadai dalam mewujudkan harapan tersebut. Salah satu variabel penting dalam hal ini adalah Kurikulum, dimana program PPK tersebut diintegrasikan dalam kurikulum yang yang sedang berjalan.

Tidak berlebihan kiranya bila banyak ahli yang berpendapat bahwa pendidikan sebagai salah satu upaya atau sarana untuk melestarikan kekuasaan negara. Michael W. Apple dalam Tilaar menjelaskan bahwa, politik kebudayaan suatu negara disalurkan melalui lembaga-lembaga pendidikannya sehingga dalam pendidikan tersalur kemauan-kemauan politik atau sistem kekuasaan dalam suatu masyarakat (Tilaar 2003, 145). Setiap kurikulum yang telah berlaku di Indonesia dari periode sebelum tahun 1945 hingga kurikulum tahun 2013, memiliki beberapa perbedaan sistem. Perbedaan sistem yang terjadi bisa merupakan kelebihan maupun kekurangan dari kurikulum itu sendiri. Kekurangan dan kelebihan tersebut dapat berasal dari landasan, komponen, evaluasi, prinsip, metode, maupun model pengembangan kurikulum. Untuk memperbaiki kekurangan yang ada, maka disusunlah kurikulum yang baru yang diharapkan akan sesuai dengan kebutuhan masyarakat dan tuntutan zaman (Kunandar 2007, 93). Artinya, perancang kurikulum selayaknya memiliki kemampuan menghadirkan masa yang akan datang pada saat sekarang, dalam 
bentuk mampu memformulasi kecenderungan dan fakta-fakta masa datang yang secara langsung berpengaruh ataupun tidak, terhadap dunia pendidikan.

Perlu diakui bahwa tidak sedikit pendekatan teoritis yang bisa dikawinkan dengan pembahasan ini baik dari era dari modernitas ke postmodernitas, dan dari strukturalisme ke poststrukturalisme. Diantaranya: Max Weber membahas tentang 'lahirnya semangat kapitalisme' sebagai bentuk mentalitas baru; Antonio Gramsci menjelaskan tentang revolusi sosial melalui hegemoni yang mensyaratkan budaya baru, yaitu kesadaran kritis; dan Pierre Bourdieu fokus pada habitus baru. Sedangkan Anthony Giddens melihat revolusi mental harus disertai perubahan struktural mendasar. Keempat teori sosial itu menjelaskan mekanisme, modalitas, peran aktor sosial dam keterlibatan macam apa saja dibutuhkan dalam perubahan sosial yang berdampak pada perubahan mindset suatu masyarakat (Haryatmoko $2017,190)$. Rasa-rasanya para expert di atas sangat menginspirasi dalam membumikan intelektualitas mereka kedalam cakrawala pokok pembahasan kali ini, namun kekuasaan lah (baca: penulis) yang membatasi ruang dialektika pemikiran tersebut.

Uraian terkait judul artikel ini tentunya melahirkan wacana dan relasi kekuasaan yang mengikatnya, kekuasaan bukan bersifat plural/sentralistik namun tumbuh dari berbagai ruang peripheral yang terdapat dari interaksi antar aktor dalam ruang inovasi kebijakan. Sangat terlihat kekuasaan sebenarnya bersifat luas dan tidak hanya terbatas dalam tatanan pemerintahan atau antara relasi pemilik modal dan pekerja. Ada cara lain yang dapat digunakan untuk menginterpretasikan ideologi. Persoalan ini akhirnya menjadi pokok perhatian dalam bahasan ini, yakni bagaimana aktor-aktor tertentu memanfaatkan konstruksi pengetahuan tentang dinamika perubahan kurikulum dan urgensitas pendidikan karakter dalam pendidikan nasional. Proses di mana pengetahuan tentang kurikulum nasional dan skema penyelesaian kasus ini dikonstruksi menggambarkan bagaimana aktor-aktor menjalankan kekuasaan. 
Menilik pada Foucault, ada beberapa prinsip metodologi yang digunakan Foucault untuk menyelidiki model relasi kekuasaan. Pertama, mengajukan pertanyaan 'bagaimana' pada persoalan kekuasaan dari pada 'mengapa' atau 'apa' adalah upaya untuk melakukan penyelidikan kritis atas tema kekuasaan, bukan mencari dasar ontologis atau metafisiknya (Foucault 1982b, 134-135). Kedua, menganalisa kekuasaan bukan pada rasionalitas internalnya, tetapi pada strategi antagonismenya. Untuk memahami apa yang disebut dengan normalitas maka yang mesti diselidiki adalah apa yang dipandang sebagai tidak normal. Untuk memahami bagaimana relasi kekuasaan, maka yang mesti diselidiki adalah pada bentuk-bentuk resistensi (Foucault 2003, 294). Ketiga, oleh karena basis relasi kekuasaan adalah adanya kebebasan, maka untuk menyelidiki relasi kekuasaan terletak pada basis adanya kebebasan, strategi, dan governmentality, bukan pada institusi politik. Jika menganalisa kekuasaan pada institusi politik maka yang didapat adalah subjek sebagai subjek hukum, yakni sebagai subjek yang memiliki dan tidak memiliki hak (Foucault 1984, 41). Keempat, menyelidiki relasi kekuasaan adalah mengkombinasikan metode penyelidikan genealogi negara dan genealogi subjek karena analisa relasi kekuasaan tidak hanya pada makro politik tetapi juga pada micro power (Foucault 1978a). Berangkat dari beberapa metodologi di atas tentunya sedikit banyak bersinggungan dengan pembahasan dalam makalah ini.

Berkaca dari prinsip metodologis dan konsep Foucault tentang kekuasaan, maka objek penyelidikan relasi kekuasaan dalam analisa genealogi kekuasaan adalah pada praktik sosial subjek, yang dimengerti sebagai tindakan atau cara seseorang bertindak. Foucault, berbicara tentang wacana, berarti berbicara tentang aturan-aturan, praktik-praktik yang menghasilkan pernyataan-pernyataan yang bermakna pada satu rentang historis tertentu (Adian 2002). Penggunaan istilah wacana diambil dari terjemahan dari discourse (discourse adalah istilah asli dalam bahasa Perancis) yang digunakan Foucault. Discourse biasanya diterjemahkan ke dalam bahasa Indonesia menjadi "wacana" 
Kebijakan Kurikulum dan Dinamika Penguatan Pendidikan Karakter

atau „diskursus", maka “wacana” dalam konteks pembahasan ini khususnya, merujuk pada konsep discourse dari Michel Foucault.

\section{B. Mobilisasi dan Konsultasi Pengetahuan: Sebuah Tinjauan Teoritis}

Sebagai langkah awal dalam menjawab pertanyaan tentang apa arti "revolusi mental" menurut kepustakaan ilmiah yang ada dan dalam sejarah. penulis memilih gagasan tentang revolusi mental yang dilontarkan oleh tiga pemikir gerakan sosial dari zaman yang berbeda. Dalam sejarah, kita mengenal beberapa tokoh pemikir sekaligus tokoh pergerakan sosial-politik yang mengadopsi konsep "revolusi mental" : Karl Marx, Chen Duxiu, dan Soekarno. Karl Marx melalui konsep materialisme sejarah menjelaskan revolusi sosial yang dengan sendirinya akan menghasilkan revolusi mental. Chen Duxiu berusaha membongkar mentalitas akibat pengaruh Konfusianisme melalui pemberlakuan demokrasi dan implementasi di semua bidang cara pemikiran ilmiah. Sedangkan Soekarno mengarahkan revolusi mental untuk nation-building agar Indonesia berdaulat serta politik, mandiri secara ekonomi dan berkepribadian secara sosial-budaya (Haryatmoko 2017, 160).

\section{Karl Marx: Revolusi Sosial Berdampak pada Perubahan Mentalitas}

Menurut Marx, sebagaimana dikutip oleh Hottois, selama masih ada institusi hak milik pribadi atas alat-alat produksi, kelas pekerja akan tetap tergantung pada pemilik modal. Hanya kaum borjuis yang bisa bebas, sedangkan pekerja tetap terbelenggu oleh kemiskinan. Pekerja diasingkan (mengalami alienasi) dari hasil pekerjaannya. Bagaimana menghapus alienasi dan membawa emansipasi sosial? Untuk menjawab pertanyaan ini, materialisme sejarah Marx mendaku sebagai jawaban yang nyata. "Materialisme" di sini berarti bahwa kegiatan dasar manusia adalah kerja sosial, bukan pikirannya. Istilah "sejarah" mengacu ke Hegel di mana sejarah dianggap sebagai proses diale- 


\section{Mohammad Ariandy}

ktis dan diterima oleh Marx. Tetapi oleh Marx, menurut Hottois, maknanya diganti bukan menyangkut perwujudan diri "Roh", melainkan perjuangan kelas-kelas unutk mewujudkan dirinya mencapai kebebasan. Tesis dan antitesis bukan mengenai "Roh subjektif" dan "Roh objektif", melainkan menyangkut kontradiksi-kontradiksi di dalam hidup bermasyarakat, khususnya dalam kegiatan ekonomi dan produksi. Sintesis akan dicapai dalam bentuk penghapusan alienasi, yaitu ketika hak milik dihapus dan masyarakat tanpa kelas tercipta. Berdasarkan asas materialistis, Marx mengandaikan bahwa kesadaran/ mentalitas tidak menentukan realitas, tetapi sebaliknya, realitas menentukan kesadaran. Realitas material itu adalah cara-cara produksi barang-barang material dalam kegiatan kerja. Perbedaan cara produksi menghasilkan perbedaan kesadaran. Kalau sistem ekonomi berubah, niscaya kesadaran/mentalitas juga berubah.

Yang dimaksud dengan basis oleh Marx adalah kekuatan-kekuatan produksi (alat kerja, pekerja, pengalaman atau teknologi) dan hubungan-hubungan produksi (antara pekerja dan pemilik modal). Di dalam basis ini terjadi kontradiksi: di satu pihak kekuatan-kekuatan produksi berkembang secara progresif, di lain pihak hubungan-hubungan produksi yang tak lain adalah hubungan-hubungan hak milik dan kekuasaan cenderung konservatif. Kontradiksi ini lama kelamaan sulit diatasi, sehingga meletuslah revolusi. Sesudah revolusi basis berubah dan suprastruktur juga akan berubah, artinya akan terjadi juga revolusi mental (Hottois 1997, 155-170). Revolusi mental Jokowi tidak menginginkan model revolusi Marx ini. Banyak darah harus ditumpahkan seperti yang terjadi di Rusia dengan Revolusi Bolshevik 1917. Secara jelas teks revolusi mental menentang model revolusi Marx semacam itu yang harus berdarah-darah membawa korban sesama saudara sebangsa. Memang ada catatan yang perlu digunakan untuk koreksi, yaitu pertama, gagasan revolusi mental ementalitas orang-orangnya; dan kedua, kalau tidak setuju dengan cara Marx menggeser kelas borjuis pemegang fasilitas-fasilitas kekuasaan yang menghambat perubahan karena kekerasan dan pertumpahan darah menjadi keniscayaan, 
Kebijakan Kurikulum dan Dinamika Penguatan Pendidikan Karakter

alternatif apa yang bisa ditawarkan dalam revolusi mental?

\section{Revolusi Mental Chen Duxiu: Revolusi Melawan Pengaruh Budaya Konfusian}

Chen Duxiu (1879-1942) adalah tokoh berpengaruh Gerakan Empat Mei 1919, yaitu gerakan politik-budaya mahasiswa yang anti-imperialis. Dia juga editor majalah New Youth (Laurence 2004, 2, 8, 12). Chen Duxiu bersama Li Dazhao merupakan pendiri Partai Komunis Cina (1921). Chen dipilih sebagai ketua yang pertama kali dan kemudian sekretaris jenderal pertama PKC. Revolusi mental yang diperkenalkan oleh Chen Duxiu belum dipengaruhi Marxisme-Leninisme, tetapi lebih dalam kerangka meninggalkan mental fatalistik untuk mengadopsi demokrasi dan cara berpikir ilmiah yang merupakan tujuan gerakan mahasiswa Empat Mei (Laurence 2004, 13). Melalui majalah New Youth itu, Chen Duxiu memperkenalkan gagasan seperti individualisme, demokrasi, metode ilmiah untuk menggantikan nilai-nilai Konfusian di dalam komunisme.

Melalui majalah New Youth, Chen mengajak orang muda untuk berjuang melawan Konfusianisme dengan menggunakan teori-teori ilmiah tentang revolusi. Lebih revolusioner lagi Chen juga menganjurkan untuk menghancurkan tradisi sehingga membuka cakrawala baru bagi kaum intelektual muda Cina. Majalah New Youth ini merupakan benih-benih Gerakan Empat Mei yang menentang hasil Perjanjian Versailles 1917 karena dianggap merugikan Cina dan menginjak harga diri bangsa Cina karena negara-negara imperialis menyerahkan semenanjung Shandong, daerah Cina yang dulu dikuasai Jerman, kepada Jepang. Dalam majalah New Youth, Chen Duxiu mengusulkan enam prinsip revolusi mental, yaitu 1) mandiri melawan perbudakan; 2) progresif melawan konservatif; 3) agresif lebih baik daripada retrogresif; 4) menjadi kosmopolitan daripada mengisolasi diri; 5) harus utilitarian sebagai ganti dari yang tidak praktis; dan 6) menjadi ilmiah daripada mengandalkan mimpi/ khalayan (Schoppa 2010, 51-52). 
Menurut Chen Duxiu, ajaran-ajaran Konfusianisme harus dibongkar dilepaskan dari dampak negatifnya, karena: pertama, menganjurkan upacara-upacara secara berlebihan dan mengajarkan moralitas kepatuhan yang penurut, yang membuat masyarakat Cina lemas, pasif, tidak cocok untuk berjuang dan bersaing di dunia modern; kedua, mengakui nilai-nilai keluarga, tetapi tidak mengakui individu sebagai unit dasar masyarakat; ketiga, mendukung ketidaksetaraan status individu; keempat, menekankan kesalehan sebagai anak naik dalam garis keluarga; dan kelima, mengajarkan pemikiran ortodoks dengan mengabaikan sama sekali kebebasan berpikir dan mengungkapkan pendapat. Jadi revolusi mental yang dicanangkan Chen Duxui belum diresapi Marxisme-Komunis, namun lebih ke arah liberalisme demokrasi pengaruh Bertrand Russel dan John Dewey (Laurence 2004, 12-13). Bahkan menurut Tai Wan-chin, baru malam menjelang Gerakan Empat Mei, Chen Duxui menerima dan mengakui pengaruh Revolusi Bolshevik (Laurence 2004, 119). Kekhasan Gerakan Empat Mei adalah, pertama, kekuatan gerakan mengandalkan pada kekuatan mahasiswa. Sejak awal sosialisasi gagasan-gagasan Chen Duxui menyasar orang muda melalui majalah yang namanya saja sudah mencerminkan lapisan masyarakat yang disasar dan semangat yang diperjuangkan, yaitu New Youth; kedua, perubahan yang dilontarkan bukan inisiatif dari kekuasaan, tetapi datang dari kesadaran sekelompok orang muda pemikir dan aktivis gerakan mahasiswa dan sosial sehingga sarat dengan aspek sukarela dan kritisisme, dua unsur penting di dalam setiap perjuangan untuk perubahan sosial (Haapanen 2013).

\section{Revolusi Mental Soekarno: Berdaulat, Mandiri secara Ekonomi dan Berkepribadian}

Soekarno memahami revolusi mental sebagai dinamika masyarakat yang mencakup tiga unsur. Pertama, revolusi adalah "proses yang dinamis-dialektis dan dialektis-dinamis, satu simfoni hebat dari kemenangan atas musuh dan kemenangan 
atas adil-diri-sendiri, satu simfoni hebat antara overwinning dan zelf overwinning. Hanya bangsa atau kelas yang dapat mengadakan simfoni yang demikian itulah dapat mencapai kemajuan dan kekuatandenganjalan Revolusi"(Soekarno1957).Kedua,Soekarno mengutip pernyataan Jawaharlal Nehru menggambarkan revolusi dengan kata "remaking" karena mengandung dinamika. Revolusi adalah gerak maju meninggalkan 'hari kemarin'(Soekarno 1957, 6). Ketiga, revolusi merupakan satu perubahan yang amat besar, diikuti pertumbuhan-pertumbuhan yang amat cepat (Soekarno 1957, 11). Revolusi membutuhkan pimpinan dinamis supaya setiap aksi tidak berdampak buruk melampaui tujuannya, yaitu barisan pelopor dan orang-orang revolusioner berpengalaman (Soekarno 1957, 12).

Revolusi mental merupakan tahap kedua setelah revolusi pembebasan, yaitu ketika bangsa masuk ke tahap nation-buliding. Ketika revolusi pembebasan, idealisme masih menyala-nyala, api keikhlasan masih bersinar terang, mission sacrèè masih merasuki jiwa pejuang, namun di tahap nation-building, idealisme itu seakan luntur, bahkan padam. Banyak penyelewengan, egosentrisme pribadi/kelompok suku, agama, partai, maka dibutuhkan revolusi mental untuk "penyucian kembali jiwa", "peremajaan", "penataan kembali", "pembangkitan kembali", atau "penggeloraan kembali" (Soekarno 1957, 15). Revolusi mental digelorakan selain karena meluasnya kelesuan bangsa, juga pimpinan bangsa tidak "rakyati" lagi sehingga mengakibatkan penyelewengan, berbagai bentuk egosentrisme serta "kerewelan" di politik. Soekarno menyebut 'kerewelan politik' karena hanya dalam tempo dua belas tahun setelah kemerdekaan, Indonesia sudah mengalami tujuh belas kali pergantian Kabinet. Demokrasi hanya dipahami sebagai kritik dan kebebasan berpendapat, lalu berkembang penyakit "doyan omong" tanpa membantu memberi solusi (Soekarno 1957, 4-5). Bahkan demokrasi ingin diterapkan di Angkatan Perang, maka berkembang ketidakpuasan di kalangan tentara (Soekarno 1957, 5). Demokrasi di Indonesia dianggap Soekarno sebagai demokrasi "hantam-kromo", asal bebas mengeluarkan pendapat. Demokrasi ini mendewakan kekebasan, tapi tidak ter- 
pimpim. Padahal menurut Soekarno demokrasi hanya alat, maka jangan sampai dikuasai alat, perlu koreksi agar demokrasi berdisplin, sesuai dengan dasar hidup bangsa (gotong-royong) yang membatasi diri pada tujuan yang satu, satu demokrasi terpimpin (Soekarno 1957, 6).

Pimpinan mencegah industrialisasi hanya tambal-sulam tanpa kebijakan yang menyeluruh, tanpa pimpinan kebijakan ekonomi tanpa arah, akibatnya harus mengimpor beras (Soekarno 1957, 1). Tiada ketahanan menghadapi pengaruh budaya asing (rock and roll, geger-ributnya swing dan jazz), dan banjirnya literatur komik melemahkan daya-cipta sastra Indonesia. Semua itu cermin menurunnya kesadaran nasional dan kekuatan jiwa nasional sehingga kurang percaya diri sebagai bangsa. Lalu menjadi bangsa penjiplak luar negeri dan kurang mempercayai satu sama lain padahal kekuatan kita ada pada jiwa gotong-royong. Kita kurang berjiwa gigih, terlalu cepat mencari gampangnya. Akibatnya, semakin menipis "rasa harkat nasional", menipis rasa-bangga dan rasa-hormat akan kemampuan dan kepribadian bangsa sendiri (Soekarno 1957, 2, 4). Soekarno prihatin banyak pemimpin sudah tidak lagi "rakyati" seperti era perjuangan kemerdekaan, padahal rakyat itu sumber kekuatan dan kepribadian bangsa, tindakan mereka mencerminkan kegigihan dan karakteristik bangsa (Soekarno 1957, 2). Maka perlu revolusi mental untuk menyadari kembali cita-cita nasional, menjadi manusia baru, berkorban guna membina bangsa.

Gerakan hidup baru revolusi mental itu meliputi: pertama, perombakan cara berpikir, cara kerja, cara hidup yang merintangi kemajuan; kedua, peningkatan dan pembangunan cara berpikir, cara kerja, dan cara hidup yang baik (Soekarno 1957, 18). Sedangkan upaya yang diusulkan oleh Dewan Nasional: hidup sederhana; gerakan kebersihan/kesehatan; gerakan pemberantasan buta huruf, membangkitkan dan mengembangkan gotong-royong; melancarkan jawatan dan perusahaan negara; gerakan pembangunan rohani; membangkitkan kewaspadaan nasional. Pemimpin gerakan hidup baru ini ada di tangan pemerintah (sipil dan militer) dan rakyat bersama (Soekarno 1957, 
16). Menurut Soekarno, perombakan mentalitas satu bangsa itu harus mulai dari pimpinannya dan terutama golongan atasnya yang dilakukan "pratidina" (setiap hari). Dengan mengutip tokoh pergerakan sosial Italia awal abad ke-20, Giuseppe Mazzini, Soekarno mengatakan: "Membaharui mentalitet satu bangsa bukan seperti orang ganti baju, manusia tidak berubah kalau rumahnya dikapur putih" (Soekarno 1957, 17). Untuk tujuan itu, butuh organisasi, butuh pimpinan yang "rakyati" dan penuh komitmen untuk hidup sederhana. Kesederhanaan yang dimaksud ialah "kesederhanaannya prajurit perjuangan yang jiwanya berkobar menyala-nyala, jiwa penuh daya cipta, jiwa anti-kebekuan yang tidak butuh emas dan berlian, nama dan kedudukan, tetapi butuh pengabdian: mengabdi kepada bangsa dan negara kesatuan".Gagasan revolusi mental Soekarno ini memperhitungkan aspek-aspek penting di dalam perubahan sosial dan budaya: perlunya organisasi, pemimpin yang "rakyati" dan punya komitmen mendalam, kesediaan untuk hidup sederhana, berkepribadian dan percaya diri.

\section{Genealogi Kuasa dan Kepentingan Aktor: Pembacaan Terhadap Kurikulum Berbasis Program "Penguatan Pendidikan Karakter" (PPK)}

Gagasan Foucault tentang konsep kekuasaan menjelaskan bahwa konstelasi kekuasaan menyerap dan bekerja dalam dunia pendidikan di Indonesia, khususnya melalui kebijakan-kebijakan yang dibuat oleh pihak-pihak yang berkepentingan dalam pendidikan. Kurikulum merupakan produk pengetahuan yang diproduksi oleh mereka yang berkuasa, salah satunya adalah negara. Undang-Undang Nomor 20 tahun 2003 tentang Sistem Pendidikan Nasional, Pasal 1 ayat 19, dinyatakan bahwa kurikulum adalah seperangkat rencana dan pengaturan mengenai tujuan, isi, dan bahan pelajaran serta cara yang digunakan sebagai pedoman penyelenggaraan kegiatan pembelajaran untuk mencapai tujuan pendidikan tertentu (UUD RI 2003, Pasal1 Ayat 19). Kurikulum merupakan alat untuk mencapai tujuan pendidi- 
kan, sekaligus sebagai pedoman dalam pelaksanaan pendidikan. Kurikulum mencerminkan falsafah hidup bangsa, ke arah mana dan bagaimana bentuk kehidupan itu kelak akan ditentukan oleh kurikulum yang digunakan oleh bangsa tersebut.

Perangsang atas hal tersebut dengan membuat kebijakan dan regulasi yang melindungi sektor strategis, bukan malah menjadi alat atas dominasi dan kendaraan aktor yang dominan untuk merebut hak aktor yang lain dengan kepentingan dan kekuasaan yang melekat pada masing-masing aktor. Menurut Foucault, adalah diciptakannya teknologi baru oleh negara tentang cara-cara spesifik mengatur, memisahkan, dan menyatukan manusia ke dalam struktur-struktur tertentu, atas nama kekuasaan dan kedaulatan, bahkan dengan mengatasnamakan kepentingan orang banyak, tetapi, pada akhirnya bertujuan melanggengkan jenis-jenis kekuasaan tertentu. Cara-cara seperti ini tidak ditemukan sebelum abad ke-17, praktik inilah yang dipahami sebagai governmentality. Namun di mata para pakar govermentalitas, muncul hubungan yang kompleks antara struktur dan relasi kekuasaan dengan proses-proses subyektivasi atau produksi subyektivitas. Menyoal tentang program penguatan pendidikan karakter yang diintegrasikan formulanya dalam kurikulum yang sedang berjalan, tentu memiliki beragam hal yang melatarbelakangi. Untuk itu salah satu hal yang mengendus dan menghegemoni kehadiran PPK ini salah satunya lahir dari rahim Full Day School (sekolah sehari penuh).

\section{Kontestasi Full Day School: Produk Penguasa 'Hidup Segan Mati Tak mau'.}

Kontestasi wacana dalam pembahasan ini mengandung arti bahwa wacana dominan dalam melihat kasus Full Day School (selanjutnya disingkat FDS) tidaklah tunggal. Ada wacana yang diseminasikan oleh penguasa yang berkontestasi dengan wacana yang diproduksi oleh para pihak kementerian baik dari Kemendikbud maupun Kemenag. Hal ini mengeksplorasi pertarungan dua wacana dominan yang berhasil mempengaruhi 
pilihan wacana Kemendikbud dan Kemenag dalam menentukan skema penyelesaian FDS. Pakar yang memandang pro terhadap FDS menampilkan persoalan wacana secara lebih spesifik, sebagai implikasi dari proses pengorganisasi produksi pengetahuan dalam memandang sebagai alternatif solusi dari revolusi pendidikan terhadap permasalahan yang terjadi di dunia pendidikan, sedangkan para pakar pendidikan yang kontra menilai, penerapan FDS ini sebagai bentuk kekeliruan menyikapi pendidikan dan persekolahan, seakan-akan pendidikan hanya identik dengan sekolah, padahal makna pendidikan jauh lebih luas. FDS sendiri adalah istilah dari proses pembelajaran yang dilaksanakan secara penuh, di mana aktifitas belajar anak dilakukan lebih banyak di sekolah daripada di rumah.

Pemaknaan terhadap FDS mengerucut dalam dua wacana dominan, yakni yang memandang FDS sebagai program yang mendatangkan banyak manfaat, khususnya ilmu pengetahuan, adanya motivasi ke peserta didik untuk melanjutkan sekolah ke jenjang yang lebih tinggi, serta dapat meningkatkan silaturrahim dengan warga sekolah baik guru, siswa, pegawai sekolah. Sedangkan pihak yang kontra berpandangan bahwa, kegiatan FDS akan menambah beban guru dan siswa. Guru bukan hanya mengurus murid-muridnya di sekolah, tetapi juga mengurusi suami, anak atau istri. Selain guru, siswa juga berpotensi mengalami kebosanan atau stres karena berada di sekolah sepanjang hari. Apalagi jika program yang direncanakan sekolah kurang menarik dan variatif, termasuk juga waktu belajar anak berkurang di sore hari seperti diniyah dan lain sebagainya. Adanya pertarungan wacana dan perebutan klaim kebenaran memberikan satu petunjuk bahwa kedua wacana tersebut masih berupa asumsi.

Tidak sedikit pemerhati pendidikan yang melakukan penolakan, termasuk dari ormas PBNU. Syafiq Hasyim, Wakil Ketua Lembaga Perguruan Tinggi Nahdlatul Ulama (LPTNU), menyebutkan dampak sekolah lima hari itu dalam artikel «Full Day School dan matinya pendidikan kaum santri». Syafiq mengatakan, sekolah 5 hari akan menimbulkan dampak lain pada keberlangsungan dan masa depan pendidikan keagamaan 


\section{Mohammad Ariandy}

khusus Islam (takhassus) yang diselenggarakan oleh madrasah Diniyyah (Madin) atau madrasah sore (Yandi 2019). Foucault menjelaskan bahwa sekolah dalam masyarakat modern telah mengotak-kotakan pengetahuan dalam beberapa kategori yang "saling terpisah". Mereka memisahkan subjek, mata pelajaran, jurusan atau program studi, yang kemudian berdampak pada individu (Martono 2014). Proses inkulkasi sebuah pandangan atau asumsi dalam melihat program FDS yang diyakini oleh aktor-aktor tertentu sebagai kebenaran. Setiap pandangan atau upaya aktor-aktor dalam mengkonstruksi pengetahuan tentang FDS berimplikasi terhadap kurikulum pendidikan nasional.

Pengembangan program FDS melahirkan pula aktor-aktor yang terlibat dengan kepentingan yang melekat. Antar aktor satu dengan yang lain berebut dinamika dan relasi kuasa untuk saling mempengaruhi praktik diskursif individu/kelompok. Loyalitas dan pengaruhnya berbeda satu individu dengan yang lain bergantung atas pengetahuan yang melekat serta seberapa kuat dialektika kuasa wacana mempengaruhi ruang publik dan kontruksi berfikir serta perilaku individu tersebut. Peraturan Presiden (Perpres) Nomor 87 Tahun 2017 tentang Penguatan Pendidikan Karakter (PPK), didukung penuh semua pihak termasuk organisasi kemasyarakatan (ormas). Penerbitan Perpres ini, terkait perbedaan pendapat, dinamika, dan penolakan terhadap kebijakan mengenai masa hari sekolah yang sebelumnya terjadi. Perpres ini terbit sebagai jawaban atas dinamika penolakan poin delapan jam kegiatan belajar mengajar yang diatur dalam Permendikbud. Aturan itu dinilai akan mematikan sekolah nonformal seperti madrasah diniyah (Stefanie 2019).

Dengan ini, kekuasaan bekerja melalui normalisasi dan regulasi. Normalisasi dianggap sebagai upaya menyesuaikan dengan norma-norma, mengadakan norma-norma. Sementara regulasi dipahami sebagai menyesuaikan dengan aturan-aturan atau mengadakan aturan-aturan sehingga kekuasaan diatur dalam kuasa wacana yang kuat mempengaruhi individu atau kelompok dalam bahasa, pikiran, pengetahuan dan tindakan atau dalam bahasa Foucault praktik diskursif (Foucault 2002, 165). 
Peraturan Presiden (Perpres) Nomor 87 Tahun 2017 tentang Penguatan Pendidikan Karakter (PPK), merupakan alat guna mendominasi massa rakyat, agar pendidikan senantiasa dikontrol dan dikuasai oleh negara. Gagasan full day school mengempis karena banyak mendapat tentangan. Muhadjir mengatakan menarik wacana sekolah sehari penuh itu. Nama program pun beralih menjadi kebijakan "Penguatan Pendidikan Karakter" (Yandi 2019). Tentunya hal ini bagian apropriasi wacana yang digulirkan pemerintah dalam rangka mengekalkan kepentingannya. Karenanya, wajar apabila hasil yang diterima peserta didik jauh dari ideal pembebasan dari kebodohan seperti yang didemagogikan oleh Kemendikbud. "Mengendapnya Asumsi menjadi Kebenaran" dalam hal ini merupakan gambaran mengenai proses mengendapnya asumsi dalam memandang status FDS menjadi kebenaran yang diyakini sebagai pandangan yang tidak perlu dipersoalkan lagi. Topik tentang program FDS tidak menjadi perbincangan yang relevan bagi masyarakat karena yang penting bagi mereka adalah pemerintah menerbitkan kebijakan baru terkait hura-hara FDS. Sebagai suguhan penutup dalam sub-bab ini, Foucault menegaskan bahwa " melalui perhitungan biaya, kegunaan hukum dan biaya penerapannya, serta oleh fakta bahwa apabila Anda tidak ingin keluar dari hukum dan Anda tidak ingin membelokkan fungsi hakikinya sebagai aturan main, maka teknologi yang harus digunakan bukanlah disiplinnormalisasi namun tindakan terhadap lingkungan. Yaitu, dengan mengubah butir-butir aturan permainannya, bukan mentalitas pemainnya (Foucault 1978, 79).

\section{Program Penguatan Pendidikan Karakter Reinkarnasi Wujud Full Day School}

"Banyak jalan menuju Roma" ini lah salah satu peribahasa yang identik melekat dengan hasrat penguasa dalam melanggengkan ideologinya (revolusi mental). Pemaknaan dari pembahasan sub-bab sebelumnya, menjadi pijakan bagi pemegang kuasa untuk kemudian merencanakan sistem, dengan perencanaan 
yang memberikan ruang kesepakatan bersama masing-masing pihak yang diberikan mandat untuk program gerakan penguatan pendidikan karakter (PPK). Dalam merencanakan proses sosialisasi, dalam konteks implementasi program tersebut dikendalikan langsung oleh Presiden melalui Kementerian Koordinator Bidang Pembangunan Manusia dan Kebudayaan (selanjutnya disebut Kemenko PMK) yang bersinergi langsung dengan Kementerian Pendidikan dan Kebudayaan (selanjutnya disebut Kemendikbud). Dalam keterangannya, Muhadjir Effendy hanya menyatakan dirinya akan menerbitkan Permendikbud baru sebagai turunan Perpres Penguatan Pendidikan Karakter.

"Kira-kira dalam minggu ini kami siapkan Permen. Termasuk kandungan Permendikbud 23 tahun 2017 yang tidak sesuai dengan perpres kan harus tidak diberlakukan" (Stefanie 2019). Adanya deal-deal politik yang terjadi dalam perencanaan program PPK, dimana pertarungan kepentingan yang terjadi antar aktor dalam menyetujui pengembangan program PPK berbasis kurikulum, bersifat sangat tertutup dan terbatas sarat akan perlindungan kepentingan konstituen. Hal tersebut terjadi karena kebijakan program FDS yang dirancang oleh Kemendikbud mendapat kritikan tajam dari sejumlah elit, dalam hal ini elit tersebut juga memiliki relasi kuasa yang pertimbangannya cukup besar bagi kepentingan politik penguasa (Presiden). Tahun politik di saat itu yang semakin dekat, menimbulkan dengan mudah lobby-lobby politik penguasa, dan hal tersebut tergolong sukses menghasilkan penguatan genealogi kuasa atas pewacanaan yang dibangun.

Penggambaran genealogi kuasa yang kuat dengan menggunakan kehadiran pemerintah atas perlindungan keberlanjutan program FDS yang berganti baju menjadi PPK menjadi keputusan final dan memberikan status atas gugurnya Permendikbud Nomor 23 Tahun 2017 tentang Hari Sekolah (Stefanie 2019). Inilah yang disebut Biopolitics bahasa Foucault, untuk menerangkan adanya relasi dominan atas kekuasaan yang masif mempengaruhi individu satu dengan yang lain, penerapannya dapat dilaksanakan dalam berbagai bentuk atau simbol yang 


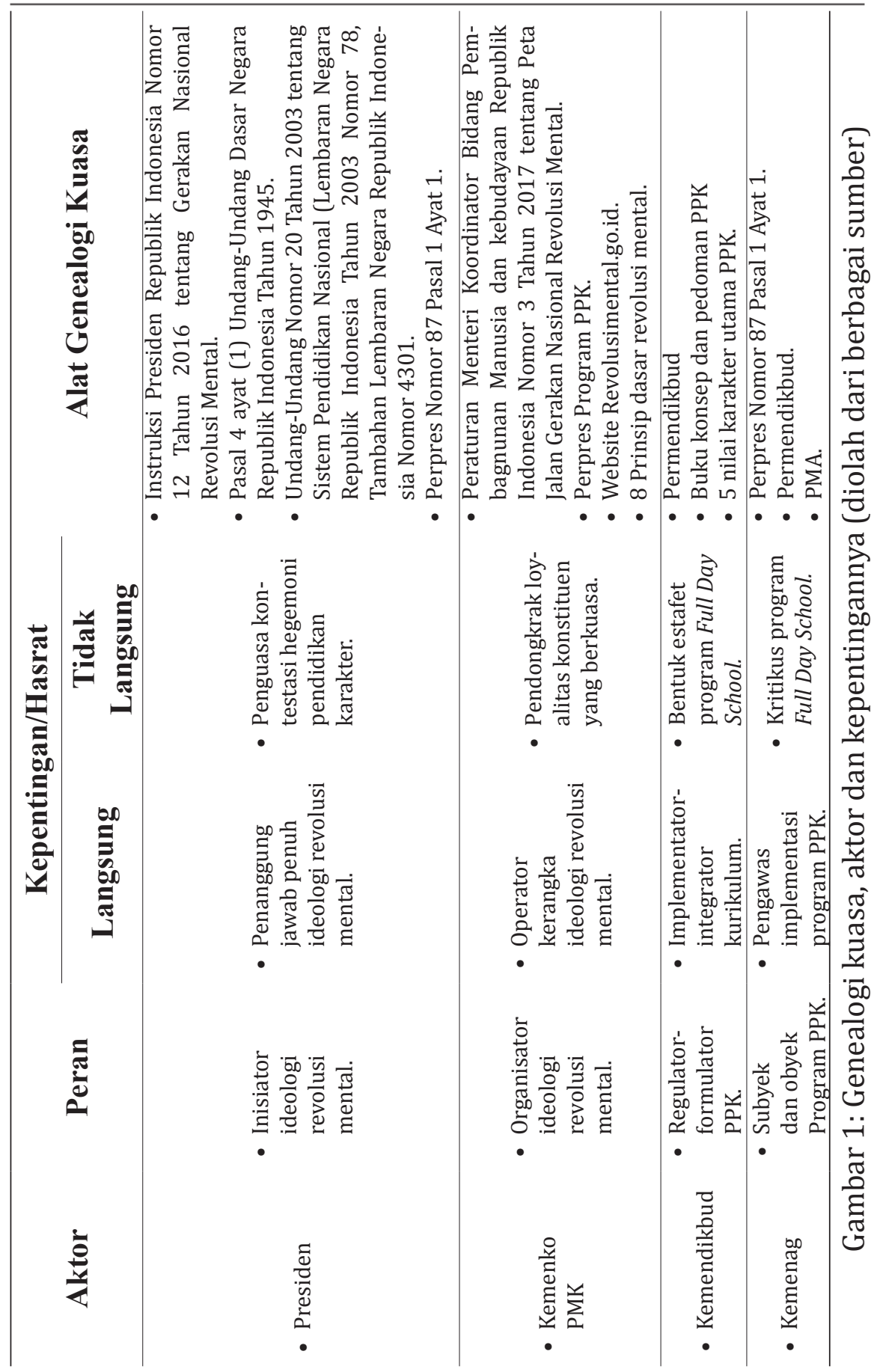


sering diistilahkan dengan symbolic violence. Simbol tersebut mempengaruhi cara berfikir, bertindak dan anggapan atas perlindungan dan penciptaan kesejahteraan yang diupayakan. Foucault (Santosa 2002, 170).

Gambar 1 menerangkan tentang gambaran sederhana terkait pola-pola kekuasaan berjalan dalam ritmenya masingmasing. Jika kekuasaan itu dipandang sebagai sistem koersif yang mendesakkan keinginannya, maka hal itu mesti dilihat sebagai 'dominasi' di mana individu dan masyarakat sebetulnya tidak menganggap penting, atau berperilaku bukan karena kehendak pribadi, untuk melakukan sesuatu yang bertujuan untuk perubahan yang mereka inginkan, melainkan semata-mata mereka melakukan itu karena perintah dari "atasan/otoritas".

\section{Integrasi Kurikulum 2013 dan Dinamika Program PPK: Suatu Tinjauan Kritis}

Belajar dari kasus Full Day School, meskipun sebuah kebijakan telah disahkan, bukan berarti rumusan kebijakan telah bebas dari berbagai permasalahan. Banyak problem yang muncul disekitar rumusan atau statemennya yang kurang atau tidak jelas. Problematika tersebut bersumber dari beberapa hal berikut ini:1) Pembuat kebijakan pendidikan kurang menguasai pengetahuan, informasi, keterangan, dan persoalan-persoalan pendidikan baik yang bersifat konseptual maupun substansial. 2) Sumber acuan para pembuat kebijakan pendidikan, baik formal maupun tidak formal berbeda-beda, oleh karena itu sikap kompromi atau jalan tengah sering diambil sebagai alternatif untuk mengakomodasikannya. Kenyataan ini yang membuat rumusan kebijakan pendidikan sering mengambang dan tidak fokus. 3) Terlalu banyak maupun kurangnya informasi bisa berakibat tidak jelasnya statemen kebijakan pendidikan. Hal ini dikarenakan kurangnya informasi menyebabkan persoalanpersoalan dan alternatif-alternatif yang dipilih menjadi terlalu sederhana. Sedangkan banyaknya informasi menyebabkan para perumus kebijakan pendidikan dihadapkan pada kesulitan 
ketika bermaksud mensintesakan persoalan dan alternatif yang akan dipilih (Hasbullah 2015, 83).

Menyoal masalah kurikulum pendidikan, tentu bukan hal yang baru dalam dunia pendidikan. Aktor adalah orang atau pelaku yang terlibat dalam proses merumuskan formulasi kebijakan yang akan memberikan dukungan maupun tuntutan serta menjadi sasaran dari kebijakan yang dihasilkan oleh sistem kebijakan. Aktor yang paling dominan dalam tahap perumusan kebijakan dengan tuntutan yang bersifat intern, dalam artian mempunyai kekuasaan atau wewenang untuk menentukan isi dan memberikan legitimasi terhadap rumusan kebijakan tersebut, disebut pembuat kebijakan (policy maker). Suatu keputusan kebijakan merupakan hasil dari interaksi antar aktor kebijakan yang masing-masing memiliki keterampilan untuk mempengaruhi, kemauan untuk menggunakan sumber daya, dan memiliki sumber-sumber pengaruh (Wibowo 2011, 1).

Pada banyak negara berkembang, kontrol pengeluaran ex-ante serta proses yang panjang untuk menyetujui pengeluaran, menyulitkan kementerian pendidikan untuk segera menanggapi keadaan yang berubah. Hal ini menghambat pelaksanaan proyek reformasi pendidikan, terutama yang membutuhkan dana kontingensi dalam jumlah besar untuk segera dikirim saat proyek berlangsung (Rondinelli 1990, 107). Selain itu, banyaknya permasalahan yang terjadi dalam waktu bersamaan seringkali menyebabkan sulitnya penentuan prioritas. Dengan sedikitnya waktu, pemerintah lebih sulit untuk mempersiapkan suatu kebijakan dan rencana tindakan yang akan dilakukan. Berpijak pada pembahasan sub-bab sebelumnya, bahwa program PPK yang terintegrasi dalam kurikulum adalah wujud baru dari huru-hara kasus Full Day School. FDS merupakan program yang lahir relatif hanya dalam hitungan minggu, (Stefanie 2019). adalah statement Muhadjir Effendy dalam berita yang dirilis oleh Cristie Stefanie salah satu kontributor CNN Indonesia.

Perlu diketahuin bahwa suatu unsur yang paling mendasar dari wacana adalah statement (Sheridan 2002, 29). Statement 


\begin{tabular}{|c|c|}
\hline $\begin{array}{l}\text { Nilai } \\
\text { Karakter }\end{array}$ & Deskripsi \\
\hline Religius & $\begin{array}{l}\text { Sikap dan perilaku yang patuh dalam melaksanakan ajaran agama yang } \\
\text { dianutnya, toleran terhadap pelaksanaan ibadah agama lain, dan hidup } \\
\text { rukun dengan pemeluk agama lain. }\end{array}$ \\
\hline Jujur & $\begin{array}{l}\text { Perilaku yang didasarkan pada upaya menjadikan dirinya sebagai orang } \\
\text { yang selalu dapat dipercaya dalam perkataan, tindakan, dan pekerjaan. }\end{array}$ \\
\hline Toleransi & $\begin{array}{l}\text { Sikap dan tindakan yang menghargai perbedaan agama, suku, etnis, } \\
\text { pendapat, sikap, dan tindakan orang lain yang berbeda dari dirinya. }\end{array}$ \\
\hline Disiplin & $\begin{array}{l}\text { Tindakan yang menunjukkan perilaku tertib dan patuh pada berbagai } \\
\text { ketentuan dan peraturan }\end{array}$ \\
\hline Kerja keras & $\begin{array}{l}\text { Tindakan yang menunjukkan perilaku tertib dan patuh pada berbagai } \\
\text { ketentuan dan peraturan }\end{array}$ \\
\hline Kreatif & $\begin{array}{l}\text { Berpikir dan melakukan sesuatu untuk menghasilkan cara atau hasil } \\
\text { baru dari sesuatu yang telah dimiliki. }\end{array}$ \\
\hline Mandiri & $\begin{array}{l}\text { Sikap dan perilaku yang tidak mudah tergantung pada orang lain dalam } \\
\text { menyelesaikan tugas-tugas }\end{array}$ \\
\hline Demokratis & $\begin{array}{l}\text { Cara berfikir, bersikap, dan bertindak yang menilai sama hak dan kewa- } \\
\text { jiban dirinya dan orang lain }\end{array}$ \\
\hline Rasa ingin tahu & $\begin{array}{l}\text { Sikap dan tindakan yang selalu berupaya untuk mengetahui lebih } \\
\text { mendalam dan meluas dari sesuatu yang dipelajarinya, dilihat, dan } \\
\text { didengar. }\end{array}$ \\
\hline $\begin{array}{l}\text { Semangat kebang- } \\
\text { saan }\end{array}$ & $\begin{array}{l}\text { Cara berpikir, bertindak, dan berwawasan yang menempatkan kepent- } \\
\text { ingan bangsa dan negara di atas kepentingan diri dan kelompoknya }\end{array}$ \\
\hline Cinta tanah air & $\begin{array}{l}\text { Cara berpikir, bertindak, dan berwawasan yang menempatkan kepent- } \\
\text { ingan bangsa dan negara di atas kepentingan diri dan kelompoknya. }\end{array}$ \\
\hline $\begin{array}{l}\text { Menghargai } \\
\text { prestasi }\end{array}$ & $\begin{array}{l}\text { Sikap dan tindakan yang mendorong dirinya untuk menghasilkan ses- } \\
\text { uatu yang berguna bagi masyarakat, dan mengakui, serta menghormati } \\
\text { keberhasilan orang lain. }\end{array}$ \\
\hline $\begin{array}{l}\text { Bersahabat/ko- } \\
\text { munikatif }\end{array}$ & $\begin{array}{l}\text { Sikap dan tindakan yang mendorong dirinya untuk menghasilkan ses- } \\
\text { uatu yang berguna bagi masyarakat, dan mengakui, serta menghormati } \\
\text { keberhasilan orang lain. }\end{array}$ \\
\hline Cinta damai & $\begin{array}{l}\text { Sikap dan tindakan yang mendorong dirinya untuk menghasilkan ses- } \\
\text { uatu yang berguna bagi masyarakat, dan mengakui, serta menghormati } \\
\text { keberhasilan orang lain }\end{array}$ \\
\hline Gemar membaca & $\begin{array}{l}\text { Kebiasaan menyediakan waktu untuk membaca berbagai bacaan yang } \\
\text { memberikan kebajikan bagi dirinya }\end{array}$ \\
\hline Peduli lingkungan & $\begin{array}{l}\text { Sikap dan tindakan yang selalu berupaya mencegah kerusakan pada } \\
\text { lingkungan alam di sekitarnya, dan mengembangkan upaya-upaya } \\
\text { untuk memperbaiki kerusakan alam yang sudah terjadi. }\end{array}$ \\
\hline Peduli sosial & $\begin{array}{l}\text { Sikap dan tindakan yang selalu ingin memberi bantuan pada orang lain } \\
\text { dan masyarakat yang membutuhkan }\end{array}$ \\
\hline Tanggung jawab & $\begin{array}{l}\text { Sikap dan perilaku seseorang untuk melaksanakan tugas dan kewa- } \\
\text { jibannya, yang seharusnya dia lakukan, terhadap diri sendiri, masyara- } \\
\text { kat, lingkungan (alam, sosial dan budaya), negara dan Tuhan Yang Maha } \\
\text { Esa. }\end{array}$ \\
\hline
\end{tabular}

\section{Gambar 2: 18 nilai karakter Kemendiknas era Susilo Bambang Yudhoyono}


Kebijakan Kurikulum dan Dinamika Penguatan Pendidikan Karakter

\begin{tabular}{|c|c|}
\hline Nilai Utama & Subnilai \\
\hline Religius & Subnilai Religius \\
\hline $\begin{array}{l}\text { Nilai karakter religius mencerminkan keberimanan } \\
\text { terhadap Tuhan yang Maha Esa yang diwujudkan } \\
\text { dalam perilaku melaksanakan ajaran agama dan } \\
\text { kepercayaan yang dianut, menghargai perbedaan } \\
\text { agama, menjunjung tinggi sikap toleran terhadap } \\
\text { pelaksanaan ibadah agama dan kepercayaan lain, } \\
\text { hidup rukun dan damai dengan pemeluk agama } \\
\text { lain. Nilai karakter religius ini meliputi tiga dimensi } \\
\text { relasi sekaligus, yaitu hubungan individu dengan } \\
\text { Tuhan, individu dengan sesama, dan individu } \\
\text { dengan alam semesta (lingkungan). Nilai karakter } \\
\text { religius ini ditunjukkan dalam perilaku mencintai } \\
\text { dan menjaga keutuhan ciptaan. }\end{array}$ & $\begin{array}{l}\text { Antara lain cinta damai, toleransi, } \\
\text { menghargai perbedaan agama dan } \\
\text { kepercayaan, teguh pendirian, percaya } \\
\text { diri, kerja sama antar pemeluk agama } \\
\text { dan kepercayaan, antibuli dan ke- } \\
\text { kerasan, persahabatan, ketulusan, } \\
\text { tidak memaksakan kehendak, mencin- } \\
\text { tai lingkungan, dan melindungi yang } \\
\text { kecil dan tersisih. }\end{array}$ \\
\hline Nasionalis & Subnilai Nasionalis \\
\hline $\begin{array}{l}\text { Nilai karakter nasionalis merupakan cara berpikir, } \\
\text { bersikap, dan berbuat yang menunjukkan kes- } \\
\text { etiaan, kepedulian, dan penghargaan yang tinggi }\end{array}$ & $\begin{array}{l}\text { Antara lain apresiasi budaya bangsa } \\
\text { sendiri, menjaga kekayaan budaya } \\
\text { bangsa, rela berkorban, unggul, dan }\end{array}$ \\
\hline $\begin{array}{l}\text { terhadap bahasa, lingkungan fisik, sosial, budaya, } \\
\text { ekonomi, dan politik bangsa, menempatkan ke- }\end{array}$ & $\begin{array}{l}\text { berprestasi, cinta tanah air, menjaga } \\
\text { lingkungan, taat hukum, disiplin, }\end{array}$ \\
\hline $\begin{array}{l}\text { pentingan bangsa dan negara di atas kepentingan } \\
\text { diri dan kelompoknya. }\end{array}$ & $\begin{array}{l}\text { menghormati keragaman budaya, suku, } \\
\text { dan agama. }\end{array}$ \\
\hline Mandiri & Subnilai Mandiri \\
\hline $\begin{array}{l}\text { Nilai karakter mandiri merupakan sikap dan } \\
\text { perilaku tidak bergantung pada orang lain dan } \\
\text { mempergunakan segala tenaga, pikiran, waktu } \\
\text { untuk merealisasikan harapan, mimpi dan cita-cita. }\end{array}$ & $\begin{array}{l}\text { Antara lain etos kerja (kerja keras), } \\
\text { tangguh tahan banting, daya juang, } \\
\text { profesional, kreatif, keberanian, dan } \\
\text { menjadi pembelajar sepanjang hayat. }\end{array}$ \\
\hline Gotong Royong & Subnilai Gotong Royong \\
\hline $\begin{array}{l}\text { Nilai karakter gotong royong mencerminkan } \\
\text { tindakan menghargai semangat kerjasama dan } \\
\text { bahu membahu menyelesaikan persoalan bersama, } \\
\text { menjalin komunikasi dan persahabatan, memberi } \\
\text { bantuan/ pertolongan pada orang-orang yang } \\
\text { membutuhkan. }\end{array}$ & $\begin{array}{l}\text { Antara lain menghargai, kerja sama, } \\
\text { inklusif, komitmen atas keputusan } \\
\text { bersama, musyawarah mufakat, tolong- } \\
\text { menolong, solidaritas, empati, anti } \\
\text { diskriminasi, anti kekerasan, dan sikap } \\
\text { kerelawanan. }\end{array}$ \\
\hline Integritas & Subnilai Integritas \\
\hline $\begin{array}{l}\text { Nilai karakter integritas merupakan nilai yang } \\
\text { mendasari perilaku yang didasarkan pada upaya } \\
\text { menjadikan dirinya sebagai orang yang selalu } \\
\text { dapat dipercaya dalam perkataan, tindakan, dan } \\
\text { pekerjaan, memiliki komitmen dan kesetiaan pada } \\
\text { nilai-nilai kemanusiaan dan moral (integritas } \\
\text { moral). Karakter integritas meliputi sikap tanggung } \\
\text { jawab sebagai warga negara, aktif terlibat dalam } \\
\text { kehidupan sosial, melalui konsistensi tindakan dan } \\
\text { perkataan yang berdasarkan kebenaran. }\end{array}$ & $\begin{array}{l}\text { Antara lain kejujuran, cinta pada ke- } \\
\text { benaran, setia, komitmen moral, anti } \\
\text { korupsi, keadilan, tanggung jawab, } \\
\text { keteladanan, dan menghargai martabat } \\
\text { individu (terutama penyandang dis- } \\
\text { abilitas). }\end{array}$ \\
\hline
\end{tabular}

\section{Gambar 3: 5 nilai karakter utama Kemendikbud era Joko Widodo (KP3K 2017, II)}


adalah sesuatu yang menjadi balok dasar bangunan utama suatu wacana. Suatu pernyataan bukanlah suatu ucapan saja, ini mengandung arti bahwa suatu kalimat sebenarnya dapat berfungsi sebagai beberapa pernyataan yang berbeda, bergantung pada konteks wacana yang ada. Serangkaian statement yang dikelompokkan menjadi beberapa wacana atau kerangka wacana yang berbeda membentuk episteme, suatu landasan pemikiran, pada suatu waktu tertentu, di mana statement tertentu dianggap sebagai pengetahuan.

Bagi Foucault, statement adalah ucapan-ucapan yang memiliki kekuatan institusional, dan karena memiliki kekuatan institusional mendapat legitimasi dari sesuatu bentuk otoritas. Ucapan-ucapan inilah yang termasuk dalam kelompok "kenyataan/realitas". Ucapan dan teks yang menciptakan klaim kebenaran serta yang disepakati sebagai pengetahuan, dapat digolongkan sebagai statement. Bila penulis sandingkan dengan temuan Rondinelli tersebut di atas, terkait penelitiannya soal kebijakan pendidikan di negara berkembang, tentu nuansa program PPK akan terasa seperti program "Kun Fayakun" atau layaknya seorang aktor sulap membacakan mantaranya "abrakadabra". Program PPK yang dalam tubuhnya melahirkan 5 nilai karakter utama yaitu religius, nasionalisme, integritas, kemandirian dan kegotongroyongan, (PPK 2019) terkesan prematur dan bersifat tumpang tindih. Untuk itu ada baiknya penulis sajikan tabel sebagai bentuk usaha memyederhanakan pemahaman terhadap fokus bahasan ini. Data ini ditampilkan guna pandangan komparatif terkait butir nilai karakter dari rezim terdahulu (Kemendiknas) dan rezim masa kini (Kemendikbud).

Berdasarkan distribusi data pada Gambar 2 dan Gambar 3, sangat jelas perbedaan jumlah butir di antara kedua rezim kepimimpinan, sekalipun keduanya memiliki orientasi yang sama terkait implementasi butir karakter. 
Kebijakan Kurikulum dan Dinamika Penguatan Pendidikan Karakter

\section{18 Nilai Karakter Era Kemendiknas Versus 5 Nilai Karakter Utama Era Kemendikbud: Sebuah Wacana Tandingan?}

Wacana di sini menjadi alat yang paling efektif digunakan untuk membentuk realitas baru. Foucault menyebutnya dengan normalisasi. Jika tidak ada counter wacana seperti Gerakan Nasional Revolusi Mental dalam program PPK terintegrasi kurikulum (wacana tandingan atau wacana perlawanan), maka apa yang semula abnormal bisa menjadi normal melalui proses normalisasi lewat penyebaran wacana tersebut. Sikap gonta ganti kurikulum tiap rezim baru berkuasa termasuk tindakan abnormal secara sosial. Tapi dapat menjadi normal sebagai hasil perselingkuhan antara pengetahuan (knowledge) dan kekuasaan (power) yang dipraktikkan melalui penyebaran wacana terus menerus secara masif. Salah satu indikator menarik yang dicatat oleh Goverment Public Relation dari Dirjen kominfo ialah analisis isi media akan Revolusi Mental diperiode bulan Juni 2015 untuk menunjukkan betapa besar minat publik dan media terhadap topik ini. Menurut catatan lembaga tersebut berita-berita yang berhubungan dengan kata kunci Revolusi Mental ditemukan 91 Berita yang muncul di media cetak ( 21 berita) dan media online (70 berita). Ada 67 berita memiliki nada yang positif , 21 berita bernada netral dan hanya 9 berita yang nadanya negatif. Adapun berita yang bernada negatif tersebut semua terbit di media online (GPR Report, edisi 5 Juli 2015, hal.6). Sebetulnya sebagian besar masyarakat menyambut positif revolusi mental sebagaimana tercermin dari jajak pendapat tersebut. Namun masyarakat akan cepat kecewa dan skeptis bila tidak segera melihat dan merasakan hasilnya. Maka identifikasi perubahan nyata perlu disosialisasikan (Haryatmoko 2017, 168).

Berangkat dari hal ini, govermentalitas membutuhkan ruang wacana sebagai tempat berlangsungnya dialektika budaya wacana kritis (the culture of critical discourse). Ruang inilah yang biasa kita sebut ruang publik (public sphere) yang diartikan oleh Habermas kurang-lebih sebagai ruang bebas kuasa-kepentin- 
gan, di mana tiap-tiap anggota masyarakat bebas untuk masuk mengemukakan pendapatnya. Tak heran ruang publik secara historis baru ditemukan pada abad ke-16 atau ke-17 karena hanya pada masa itu terjadi industrialisasi tahap awal. Habermas sendiri mengklaim bahwa ruang publik pada mulanya adalah ruang borjuis, tempat di mana mereka membicarakan urusan ekonomi, politik, sosial- kemasyarakatan. Pada masa ini pula muncul cikal-bakal status kewargaan (citizenship) menggantikan tema-tema keagamaan yang dominan pada Abad Pertengahan. Tema-tema yang dibicarakan tak jauh dari minat governmentality. Apa yang mereka utarakan dianggap sebagai bagian perlawanan dari civil society. Dengan kata lain, ruang publik yang dimaksudkan sebagai ruang bebas kepentingan pada awalnya, dan terus sampai sekarang, adalah tempat ide-ide mem-back-up kekuasaan diterapkan. Pada titik ini kekuasaan bukan lagi sebuah dominasi, tetapi sebuah kekuatan yang mengikutsertakan orang-orang dalam suatu pergulatan wacana-wacana. Inspirasi gagasan tidak lagi datang dari subjek yang murni terlepas dari ruang-ruang wacana, melainkan bentuk reaksi dan relasi terhadap gejolak perubahan-perubahan sosial yang terus terjadi. Tetapi, semua ini bekerja dengan prinsip dialektis; kekuasaan yang dilihat sebagai wacana selalu membutuhkan counter-discourse sebagai wacana tandingan dalam budaya wacana kritis yang sudah terhegemoni. Akibatnya, pandangan-pandangan alternatif tak lain dari pseudoalternatif yang sudah larut dalam budaya wacana dominan. Pada hal ini Foucault mengartikan governmentality sebagai 'singular generality' karena sifat kemaha-satuannya.

The analysis of governmentality as singular generality implies that 'everything is political'. This expression is traditionally given two meanings ; first, politics is defined by the whole sphere of state intervention,... to say that everything is political amounts to saying that, directly or indirectly, the state is everywhere. Second, politics is defined by the omnipresence of a struggle between two adversaries... this other definition is that of K.(sic) Schmitt. (Foucault 2007, 505).

Foucault tidak memberi perbedaan antara wacana dominan 
Kebijakan Kurikulum dan Dinamika Penguatan Pendidikan Karakter

dengan wacana tandingan. Wacana tandingan dianggap tidak mampu, atau bahkan terkontaminasi dengan ide-ide kekuasaan. Bahkan ia tidak membedakan pengertian politik sebagai pertentangan antara 'kawan/lawan'nya Carl Schmitt. Dua-duanya masih dianggap tidak bisa lepas dari hegemoni dominan. Hal ini berkaitan dengan minat intelektual Foucault yang ingin menjelaskan dengan ketat bagaimana kekuasaan itu bekerja, bukan ingin menjawab bagaimana cara mengakhiri sebuah kekuasaan. Foucault amat informatif dalam menyampaikan ide-ide relasi dalam wacana pengetahuan dan kekuasaan sekaligus amat longgar dalam mendefinisikan apa itu pengetahuan dan apa itu kekuasaan. Hal ini sebagai risiko digunakannya perspektif wacana dalam melihat sebuah pergulatan intelektual. Yang dipentingkan adalah relasinya, bukan definisi, dengan risiko betapa pun keras usahanya.

Dinamika gerakan nasional revolusi mental melalui program PPK berbasis kurikulum nampak nyata pada tataran praksis. Penguasaan atas jaringan wacana/normalizing judgment yang kuat menjadi faktor dari hal tersebut. Jaring normalizing judgment memiliki beragam bentuk (Foucault 1990, 96). Bentuk tersebut akan mempengaruhi ruang operasionalitas atas kekuasaan lewat legitimasi. Legitimasi atas pelanggengan pewacanaan genealogi kuasa pada ruang publik misalnya: mengklaim 85.000 sekolah pelaksana PPK menjadi sekolah rujukan dan percontohan (BKLM 2019). kemudian adanya deklarasi komite sekolah mendukung program PPK (Yuniarti 2019) dan kabar sekolah terapkan PPK, siswa jadi betah belajar (Widianto 2019). Bentukbentuk legitimasi di atas penulis berargumen adalah bagian dari "Subjektivasi". Bagi Foucault kekuasaan beredar dalam suatu masyarakat, bukan hanya dimiliki oleh suatu kelompok. Kekuasaan merupakan suatu bentuk tindakan atau hubungan antar kelompok. Kekuasaan merupakan sebuah bentuk tindakan atau hubungan antar individu dalam masyarakat yang selalu dinegosiasikan dalam setiap interaksi, dan tidak pernah bersifat stabil. Foucault menolak ide tentang kekuasaan yang represif belaka, karena menurutnya pasti selalu ada negosiasi dari pihak yang 
mendapat tekanan dari semua pihak. Di mana ada kekuasaan, secara otomatis akan ada pula resistensi, artinya tidak ada kekuasaan yang menjadi dominasi total.

Berdasarkan keterangan tersebut penulis menutup pembahasan ini dengan mengamini apa yang di paparkan oleh Foucault tentang cara-cara kuasa beroperasi, Pertama, kekuasaan tidak diperoleh, diambil, dibagikan, karena kekuasaan berjalan dari berbagai titik. Kedua, kekuasaan bersifat cair dan tidak ada yang diuntungkan dan dirugikan, semua aktor harus saling rela membagi kuasa dan fasilitasi peningkatan kesejahteraan. Ketiga, hubungan kekuasaan tidak berada dalam posisi suprastruktur, kekuasaan datang dari bawah artinya tidak ada oposisi binair antara yang mendominasi dengan yang didominasi. Keempat, hubungan kuasa bersifat intensional, artinya tidak ada kuasa tanpa rangkaian rasionalitas kuasa. Kelima, kekuasaan selalu mengandung resistensi, karena resistensi bagian dari kuasa itu sendiri (Haryatmoko 2014, 96).

\section{E. Kesimpulan}

Diskursus kurikulum pendidikan dalam gerakan nasional revolusi mental; genealogi kuasa terhadap dinamika penguatan pendidikan karakter dalam artikel ini, dengan sadar terilhami dari taksonomi post-stukturalisme ala Michel Foucault. Artikel ini intens menyoroti terkait hal-hal yang melatarbelakangi kebijakan kurikulum pendidikan, khususnya pendidikan karakter dalam bingkai program "penguatan pendidikan karakter" (PPK). Hal tersebut tentunya tidak lepas dari inovasi kebijakan kurikulum yang dikawinkan dengan gagasan-gagasan pemerintah yang dibalut dalam sebuah gerakan dengan label 'revolusi mental', yang terintegrasi dalam sebuah kurikulum nasional yang sedang berjalan. Dalam uraian terkait judul pembahasan ini tentunya melahirkan wacana dan relasi kekuasaan yang mengikatnya. Kekuasaan bukan bersifat plural/sentralistik namun tumbuh dari berbagai ruang peripheral yang terdapat dari interaksi antar aktor dalam ruang inovasi kebijakan. Sangat terlihat kekuasaan 
Kebijakan Kurikulum dan Dinamika Penguatan Pendidikan Karakter

sebenarnya bersifat luas dan tidak hanya terbatas dalam tatanan pemerintahan atau antara relasi pemilik modal dan pekerja.

Wacana PPK tidak pernah mengarah pada sekumpulan argumen yang saling menegasikan. Wacana sebetulnya menyembunyikan apa yang tidak tersampaikan oleh argumen itu sendiri. Sama halnya kekuasaan bersembunyi di ruang antara itu. Teori governmentality secara efektif menunjukkan wacana yang hanya menjadi medium mengantarkan kekuasaan. Persoalan yang akhirnya menjadi pokok perhatian dalam artikel ini, yakni bagaimana aktor-aktor tertentu memanfaatkan konstruksi pengetahuan tentang dinamika perubahan kurikulum dan urgensitas pendidikan karakter dalam pendidikan nasional. Proses di mana pengetahuan tentang kurikulum nasional dan skema penyelesaian kasus ini dikonstruksi menggambarkan bagaimana aktor-aktor menjalankan kekuasaan. Kekuasaan yang didudukkan sebagai relasi harus dipandang sebagai sebuah kemenangan political rationality yang bukan tanpa masalah. Ketika masingmasing individu dengan kelas sosial khusus di masyarakat merasa perlu melibatkan diri dalam suatu pergulatan diskursus, atau merasa menjadi bagian dari dinamika kekuasaan-kekuasaan sebagai bagian dari dirinya, (gerakan nasional revolusi mental) ia akan "terpanggil" untuk ikut serta menyongsong apa yang hadir di sekitarnya (Subjectivation). Pada saat itulah sublimasi ideologi kekuasaan berpotensi mengecoh obyeknya. Segala wacana yang dikembangkan Foucault "which has the population as its target, political economy as its major form of knowledge, and apparatus of security as its essential technical instrument" bukan saja menjadi kenyataan, tetapi juga berhasil menghaluskan dampak-dampak ekstrem dari perbedaan-perbedaan di masyarakat.

Jika kekuasaan secara hierarkis memaksakan kehendakkehendaknya kepada masyarakat, maka cara seperti ini butuh alokasi dan mobilisasi sumber daya dan kekuatan yang tidak sedikit. Kekuasaan justru akan semakin efektif jika berhasil menggerakkan serta mengarahkan individu-individu untuk bertingkah laku secara sukarela. Keadaan sebisa mungkin dibuat normal-normal saja, dengan begitu, akan tercipta masyarakat 
yang berdisiplin, taat regulasi, dan membatasi diri pada aturanaturan yang telah diciptakan. Kekuasaan bukan lagi sekadar mengontrol, ia bahkan didukung oleh individu-individu yang merasa menjadi bagian darinya, sehingga masing-masing dari mereka mengambil sikap "etis" terhadap persoalan-persoalan atau wacana-wacana yang dihadapi. Artikel ini mencoba mengajukan tesis bahwa kekuasaan adalah bentuk subjektivisme yang telah terfilter, sehingga berhasil mengaburkan bentuk-bentuk ketidaksadaran ke dalam aktivitas sosial manusia. Ketidaksadaran atau lebih tepatnya ketidakmungkinan justru menguasai dinamika dalam diskursus itu sendiri. Teori ini (governmentality) akan berguna sebagai kritik kekuasaan sekaligus memberi perspektif dalam melihat kekuasaan itu sendiri. Demi terciptanya highly-organized society suatu model masyarakat yang solid yang tidak terikat sama sekali dengan kekuasaan. Kekuasaan dalam artikel ini memang relatif cenderung dipandang negatif dan walaupun ada sesuatu yang baik dari kekuasaan, itu tak lain dari upaya mencari legitimasi baru bagi kepentingan relasi kuasa/ para aktor yang akan diwujudkan dalam waktu yang lain.

\section{BIBLIOGRAPHY}

Foucault. 2007. Security, Territory, Population: Lectures at The College de France 1977-1978. Palgrave Maccmillan.

Foucault. 2003. Society must be Defended. UK: Penguin Books.

Foucault. 2002. The Archeology of Knowledge. Trans. Alan Sheridan. Oxon: Routledge.

Foucault. 2002. Power/Knowledge. Trans. Yudi Santosa. Yogyakarta: Bentang Budaya.

Foucault. 1990. The History of Sexuality: An Introduction, Vol 1. New York: Vintage Books.

Foucault. 1984. The Ethics of the Concern of the Self as a Practice of Freedom. In The Essential Foucault. New York: The New Press. Foucault. 1982. The Subject and Power In The Essential Foucault. New York: The New Press. 
Kebijakan Kurikulum dan Dinamika Penguatan Pendidikan Karakter

Foucault. 1978. Governmentality. In The Essential Foucault. New York.: The New Press.

Tilaar, H.A.R. 2003. Kekuasaan dan Pendidikan. Magelang: Indonesia Tera.

Haapanen, Jarkko. 2013. Adaptation to World Trend: A Reading of the May Fourth Movement Radicalization. Jyvaskyla: University Library of Jyvaskyla.

Haryatmoko. 2017. Critical Discourse Analysis (Analisis Wacana Kritis): Landasan Teori, Metodologi dan Penerapan. Jakarta: Rajawali Pers.

Hottois, Gilbert. 1997. De la Renaissance à la Postmodernité. Brussels: De Boeck et Larcier.

Kementerian Pendidikan Nasional Republik Indonesia. 2010. "Kebijakan Nasional Pembangunan Karakter Bangsa". Jakarta: Pusat Kurikulum Balitbang Kemendiknas.

Kementerian Pendidikan dan Kebudayaan. 2017. Konsep dan Pedoman Penguatan Pendidikan Karakter. Cetakan Kedua.

Kunandar. 2007. Guru Professional, Implementasi Kurikulum Tingkat Satuan Pendidikan (KTSP) dan Persiapan Menghadapi Sertifikasi Guru. Jakarta: Raja Grafindo Persada.

Laurence, Alan. 2004. China since 1919-Revolution and Reform: a Source Book. London: Routledge.

Hasbullah N. 2015. Kebijakan Pendidikan: Dalam Perspektif Teori, Aplikasi, dan Kondisi Objektif Pendidikan di Indonesia, Depok: RajaGrafindo Persada.

Martono N. 2014. Sosiologi Pendidikan, Jakarta: PT Grafindo Perkasa.

Schoppa, R. Keith. 2010. Revolution and its Past: Identities and Change in Modern Chinese History. Upper Sadle River, N.J: Prentice Hall.

Soekarno, 1957. Amanat Presiden Soekarno pada Ulang Tahun Proklamasi Kemerdekaan Indonesia, 17 Agustus 1957 di Jakarta.

Adian, Donny Gahral. 2002. "Menabur Kuasa Menuai Wacana”. 
BASIS vol. 51 no. 01-02.

Rondinelli D.A., J. Middleton, \& A.M. Verspoor. 1990. Planning Educational Reforms in Developing Countries: The Contingency Approach. Durham: Duke University Press.

Maimunah. 2013. "Relasi Politik Pendidikan dan Politik Kekuasaan”. AL-AFKAR Journal for Islamic Studies, Vol. 2, No. 2.

Wibowo, Udik Budi. 2011. "Intensitas Peran Aktor Kebijakan Dan Kekuatan Politis Dalam Perumusan Kebijakan Sertifikasi Pendidik". Jurnal Penelitian Ilmu Pendidikan, Vol. 4 No. 1. 